\title{
Tourism as a Barometer of Unequal Exchanges among Afro- Eurasian Countries
}

\author{
Victor Shaw, Ph.D.* \\ Department of Criminology and Justice Studies, Department of Sociology, California State University- \\ Northridge, Northridge, CA 91330-8457, USA
}

*Corresponding Author: Victor Shaw, Ph.D., Department of Criminology and Justice Studies, Department of Sociology, California State University-Northridge, Northridge, CA 91330-8457, USA

\begin{abstract}
This paper follows tourism as a barometer to examine unequal exchanges among countries in the world, especially across Afro-Eurasia. Discrimination is described and analyzed in five sections. "The Particular" presents the situation from the observation and experience of a regular individual. "The Discriminator" focuses on discriminators and their acts of discrimination whereas "The Victim" draws attention to victimizations suffered by individual citizens and countries under the situation. "The Compromise" presents both sides and their respective perspective to see how the situation, problematic though, sustains itself as part of social equilibrium and as an episode of the everyday life continuum. Finally, "the Universal" attempts to uncover and learn from the situation something general and significant, sociologically or otherwise.
\end{abstract}

Keywords: Tourism, Discrimination, International Relations, Afro-Eurasia

\section{INTRODUCTION}

Tourism is now an important part of economy. Neutral by itself though, tourism is not a fair game for every country in the world. Countries in the North attract more visitors than their counterparts in the South with better advertisements about cultural heritages and social achievements. Nations in the West draw more tourists than their competitors in the East by commercials on material amenities and physical infrastructures (Wallerstein1984; Kerbo2005; Chen and Ravallion2010; Boeri, Brucker, Doquier, and Rapopor2012; Feenstra and Taylor2013; Bansak, Simpson, and Zavodny2015; World Bank2017; Stangland Pesonen2018).

At an individual level, it is quite natural that well-to-do citizens in poor countries would be willing to save hard and smart through much of their lives for one-of-a-lifetime trips to Europe or North America while commoners in rich nations might not even bother to travel to some developing, underdeveloped, or undeveloped territories with just what they would normally spend on a few meals at local restaurants (Miller20016; Pearce and Wu2016; Widawski and Wyrzykowski2016).

\section{THE PARTICULAR}

Living in the Unites States, Alibaba has the opportunity to receive and entertain a considerable number of visitors year after year from his land of birth which by measure of development remains far behind America.

The visitors Alibaba sees from his homeland range from officials, businesspeople, and intellectuals to young students. Whether they are on business trips or for individual leisure, they take time to visit major sites across America. They spend on lodging, airfare, ground transportation, and other tourist services typically more than any average American traveler would pay for the same or similar expenditures because they are not familiar with local markets. They purchase name-brand consumer goods often with extravagance even by American standards because they figure they can only buy those luxuries once in the United States. They pay colleges, universities, and other training programs for workshops and classes even though they already know what they can actually learn from those assumedly knowledge-centered exercises. Some of them even pay hefty fines for traffic tickets as they mistake the Unites States as a land of freedom on freeways. When asked why they feel seemingly so easy with their expenses in America, they almost say the same: "It's only once in our lifetime; we've 
saved hard for this trip; and we'll figure out how much more we have to squeeze from our everyday life when we get home." Indeed, Alibaba knows it too well that the considerable amount of money lavishly pumped into American economy by visitors from his homeland uniformly costs a great deal of hardship not only to those lucky visitors themselves but also to many more people around them for quite long time.

As an enthusiastic traveler, Alibaba also has numerous observations as how tourists from advanced economies spend in poor countries. First, youths and students stay in hostels, drink coca colas, eat at Western fast chains, and use public transportations. They spend minimally, with some of their expenditures even channeling back to their home economy through multinational corporations or other avenues. In Africa and South America, Alibaba meet many European tourists who stay in hostels and budget lodgings owned by people from Britain, France, Holland, and Spain. Second, expatriates from advanced societies enjoy hospitalities provided by their relatives and friends when they visit their hometowns. Alibaba knows for himself that he does not spend much out of his own pocket every time he meets his classmates and family members on the land of his birth. Third, middleclass vacationers make smart plans and tend to stay with name-brand establishments for lodging, eating, and entertainment operated by multinational corporations. For example, Alibaba arranges to eat lunch at McDonald's, Subways, or Kentucky Fried Chicken, overnight at Holiday Inn, Hilton, or Sheraton, join tours with Gray Line, and rent cars from Hertz, Avis, or Budget when he vacations with his family in Chile, Egypt, India, Malaysia, Mexico, and Thailand. Finally, business travelers, such as engineers, technicians, layers, scholars, consultants, managers, and executives from advanced countries, conduct business often at the cost of enterprises, universities, or governmental agencies in poor nations. While they may make money handsomely, they rarely have any category to spend it like a typical tourist.

\section{THE DISCRIMINATOR}

It is not immediately clear as whom discriminators are in the unfair flow of visitors, visits, and spending in tourism. In general terms, the market may be called the perpetrator because it favors the developed, the commercialized, and the advanced to the disadvantage of the undeveloped, the unmarketed, and the lagged-behind. Or the world system may be assigned blame because it benefits the rich, the powerful, and the knowledgeable at the cost or suffering of the poor, the powerless, and the illiterate. As part of the system, mass media serve as major mouthpieces in spreading positive images about rich nations while presenting negative portrayals about poor countries. For example, some signs and warnings on destination guidebooks or over travel channels can scare off interested tourists from ever planning vacations to a broadly perceived poor or troublesome society whereas a few words and pictures in world almanacs or on television programs may motivate inspired individuals to spend their lifetime savings on trips to an assumedly advanced or sophisticated culture (Wallerstein1997; Simon1997; Therborn2006; Ray 2007; Keating2011; Griffiths2012; Feenstra and Taylor2013; Mowforth and Munt2016; Vitalis 2017; Atkinson2018).

Individuals can reasonably be named discriminators to some extent as well. First, most travelers follow their commonsensical knowledge and comfort fed and nurtured by the mass media to choose developed over undeveloped destinations even though they know they could help or hurt local economies by visiting or avoiding particular places with or without tourist expenditures. Second, tourists from advanced countries use information and other built-in advantages to find bargains and minimize spending while traveling in backward territories, leaving minimal income to local merchants and service providers. Third, travel agents, merchants, and well-off everyday residents in advanced societies may make travelers from poor nations spend beyond capacity either because they set prices for travel and leisure naturally high amid their affluent standards of living or because the latter do not want to look miserable and shabby in front of the former. Finally, travelers from poor countries have to find savings or wrench profits from people around them on their native land, from friends, relatives, and employees, to merchants, in order to support their trips, sometimes once in a lifetime, to an advanced destination (Saufi and Andilolo2016; Widawski and Wyrzykowski2016).

\section{THE VICTIM}

The uneven and unequal flow of tourists and tourist spending has immediate impacts upon developing, underdeveloped, and undeveloped economies. On the one hand, they have to sell cheap and save hard to earn and muster foreign currencies to support their diplomatic missions and pay for 
international trips made by a minority of their social elites. On the other hand, they find it difficult to collect revenues from tourism to build infrastructures, establish services, and improve advertisements. Major natural and cultural sites struggle in dire conditions. The whole tourist industry remains undeveloped or in weak shapes. The situation opens the door for either avoidance by international visitors or takeover by foreign corporate interests. Ironically, some lodgings, transportations, and even food services surrounding some significant travel sites in some poor countries are actually in the hands of some enterprises and entrepreneurs from rich nations (Shultz 1998; Kerbo2005; Feenstra and Taylor2013; Berliner, Greenleaf, Lake, Levi, and Noveck2015).

The ultimate victims are individuals who labor in poor societies. Around tourist sites and travel services, craftspeople make souvenirs in days for little credit, merchants attend shops in hours without much income, porters carry loads through thousands of stairs up to some mountainous sites for a meager salary, and taxicab drivers plow through a whole city for a whole night without a decent earning. Alibaba hired drivers with their taxicabs in Bulgaria, Ecuador, Egypt, India, Indonesia, and the Philippines. At the time of each car hiring, he could not literarily comprehend how a taxicab driver makes ends meet with so little earned from a long day of numerous trips spent with a foreign customer. Close to people who travel to affluent countries, parents sacrifice lifetime savings to send children to study in the West, employees work long hours and take minimal pays to support owners or management executives to vacation in foreign resorts or make business trips to advanced societies, and even friends and relatives may have to pool funds and resources so that one can fulfill one's dreamed visit to a developed destination.

\section{THE COMPROMISE}

From a third-party's point of view, developed societies indeed provide more advanced tourist infrastructures, better consumer goods, higher traveler services, and broader a variety of visitor attractions. Travelers from poor countries pay for similar services and treatments like everyone else. Some of them pay a little more on certain occasions often because they do not know enough about the occasion, not because they face any intentional discrimination under the circumstance (Wallerstein1997; Shultz1998; Kerbo2005; Therborn2006; Ray2007; McDonough2009; Beck2011; Edwards2011; Todaro and Smith2011; Griffiths2012; Feenstra and Taylor2013; Yap and Gibb2013; Bansak, Simpson, and Zavodny2015; Miller2016; Pearce and Wu2016).

Developing, underdeveloped, and undeveloped countries, in contrast, do often not offer much more than some natural landscapes and cultural sites that happen to sit on their territories. Travelers from rich nations may not need to dig much into their pockets for expenditures. However, given what they are so accustomed to in their everyday living at home, they are likely to have to bear a considerable amount of inconvenience, discomfort, trouble, worry, and even fear when they travel in poor countries.

For those who labor around travel sites in poor economies, they at least have opportunities to make a living. Without foreign tourists, they might have to struggle even harder in their life. For those who save for a few privileged individuals to travel to advanced societies, they may learn or benefit from the stories related to them, pictures shown to them, and, most important, new perspectives, approaches, or attitudes taken toward them by their business owners, managerial executives, family members, or close friends upon completion of the trip.

\section{CONCLuSion}

Good places attract people. Advanced societies evoke awe, mystery, and sensation among people around the world. Citizens of poor nations dream to see them as models, sources of inspiration, or wonderlands whereas residents of rich countries want to visit them as competitions, references, or playgrounds. Developed economies hold wealth, information, technology, and other resources to invest in tourism, promote travel attractions, and deliver hospitality services. Visitors spend in the system, enjoy over the process, and leave with memorable experiences. An overall positive public impression makes all developed or advanced countries or territories taken-for-granted places or attractions for leisure, business gathering, and luxury living.

Negative images scare off travelers. Stereotypes take deep roots in the minds of people about political instability, economic poverty, or civil disorderliness in many countries in the developing world. Diplomats, missionaries, technocrats, and managers take assignments to those places as dangerous 
challenges. Travelers include those destinations in their map of adventure only if they hold some unique perspectives for, special connections to, or unfathomable passions toward them. However, when news breaks out over tourist kidnapping, infectious disease, or civil disturbance, all business and leisure travels can halt to an indefinite standstill in any one of the poor nations on the face of the earth.

It takes time and efforts for a place to be found and visited as a site of cultural significance or natural uniqueness. Lacking resources, small, poor, or otherwise marginalized countries will need to invest a lot more than normal to put any of their deserving attractions on the list for world tourists. On the other hand, once a place is established as a renowned travel attraction either by convention, timing, or luck, it tends to stay so for a long time. Leading in development, large, rich, or otherwise centerpositioned nations will not need to do much to benefit from series of visits by throngs of visitors to some of its worthy sites in the global market of tourism.

\section{REFERENCES}

[1] Atkinson, A.B. 2018. Inequality: What Can Be Done? Cambridge, MA: Harvard University Press.

[2] Bansak, C., Simpson, N., and Zavodny, M. 2015. The Economics of Immigration. New York: Routledge.

[3] Beck, U. 2011. "Cosmopolitanism as Imagined Communities of Global Risk." The American Behavioral Scientist 55 (10): 1346-1361.

[4] Berliner, D., Greenleaf, A., Lake, M., Levi, M., and Noveck, J. 2015. Labor Standards in International Supply Chains: Aligning Rights and Incentives. Northampton, MA: Edward Elgar Publishing.

[5] Boeri, T., Brucker, H., Doquier, F., and Rapopor, H. 2012. Brain Drain and Brain Gain: The Global Competition to Attract High-Skilled Migrants. Oxford, UK: Oxford University Press.

[6] Chen, S.H. and Ravallion, M. 2010. "The Developing World is Poorer than We Thought, but No Less Successful in the Fight against Poverty." Quarterly Journal of Economics 125(4):1577-1625.

[7] Edwards, R.D. 2011. "Changes in World Inequality in Length of Life: 1970-2000."Population and Development Review 37(3): 499-528.

[8] Ernst, D. and Plummer, M.G. 2018.Megaregionalism 2.0: Trade and Innovation within Global Networks. Singapore: World Scientific Publishing.

[9] Feenstra, R.C. and Taylor, A.M. 2013. International Trade. New York: Worth Publishers.

[10] Griffiths, R. 2012. Annual Editions: Developing World 13/14. New York: McGraw Hill.

[11] Keating, J.E. 2011. "Rich Country, Poor Country.” Foreign Policy 188: 1-3.

[12] Kerbo, H. 2005. World Poverty: The Roots of Global Inequality and the Modern World System.

[13] McDonough, T. (2009). The Situationists and the City: A Reader. New York: Verso.

[14] Miller, A.P. 2016. Sustainable Ecotourism in Central America: Comparative Advantage in a Globalized. Lanham, MD: Lexington Books.

[15] Mowforth, M. and Munt, I. 2016. Tourism and Sustainability: Development, Globalisation and New Tourism in the Third World. New York: Routledge.

[16] Pearce, P.L. and Wu, M.Y. 2016. The World Meets Asian Tourists: Bridging Tourism Theory and Practice. Bingley, UK: Emerald Publishing.

[17] Ray, L. 2007. Globalization and Everyday Life. New York: Routledge.

[18] Saufi, A. and Andilolo, I.R. 2016. Balancing Development and Sustainability in Tourism Destinations: Proceedings of the Tourism Outlook Conference 2015. Singapore: Springer.

[19] Schultz, T.P. 1998. "Inequality in the Distribution of Personal Income in the World: How It is Changing and Why." Journal of Population Economics 11(3): 307-344.

[20] Simon, D. 1997. "Development Reconsidered; New Directions in Development Thinking." Human Geography 79(4): 183-201.

[21] Stangl, B. and Pesonen, J. 2018. Information and Communication Technologies in Tourism 2018: Proceedings of the International Conference in Jönköping, Sweden, January 24-26, 2018. Cham, Switzerland: Springer.

[22] Therborn, G. 2006. Inequalities of the World: New Theoretical Frameworks, Multiple Empirical Approaches. New York: Verso Books.

[23] Todaro, M.P. and Smith, S.C. 2011. Economic Development. Upper Saddle River, NJ: Prentice Hall.

[24] Vitalis, R. 2017. White World Order, Black Power Politics: The Birth of American International Relations. Ithaca, NY: Cornell University Press. 
[25] Wallerstein, I. 1984. The Politics of the World-Economy: The States, the Movements, and the Civilizations. Cambridge and New York: Cambridge University Press.

[26] Wallerstein, I. 1997. The Capitalist World Economy. Cambridge and New York: Cambridge University Press.

[27] Widawski, K. and Wyrzykowski, J. 2016. The Geography of Tourism of Central and Eastern European Countries. Berlin: Springer.

[28] World Bank. 2017. World Development Indicators 2017. Washington, DC: World Bank.

[29] Yap, O.F. and Gibb, R. 2013. Annual Editions: Comparative Politics 13/14. New York: McGraw Hill.

Citation: Victor Shaw, Ph.D. "Tourism as a Barometer of Unequal Exchanges among Afro-Eurasian Countries" International Journal of Research in Sociology and Anthropology (IJRSA), vol 4, no. 2, 2018 , pp. 1-5. doi:http://dx.doi.org/10.20431/2454-8677.0402001.

Copyright: (C) 2018 Authors. This is an open-access article distributed under the terms of the Creative Commons Attribution License, which permits unrestricted use, distribution, and reproduction in any medium, provided the original author and source are credited. 